\title{
Article \\ Characterization of a Lactiplantibacillus plantarum R23 Isolated from Arugula by Whole-Genome Sequencing and Its Bacteriocin Production Ability
}

\author{
Joana Barbosa ${ }^{1, *,+}$, Helena Albano ${ }^{1,+}$, Beatriz Silva ${ }^{2}$, Maria Helena Almeida ${ }^{3}$, Teresa Nogueira ${ }^{4,5}$ and \\ Paula Teixeira ${ }^{1, *(\mathbb{D})}$
}

check for updates

Citation: Barbosa, J.; Albano, H.; Silva, B.; Almeida, M.H.; Nogueira, T.; Teixeira, P. Characterization of a Lactiplantibacillus plantarum R23 Isolated from Arugula by Whole-Genome Sequencing and Its Bacteriocin Production Ability. Int. J. Environ. Res. Public Health 2021, 18, 5515. https://doi.org/10.3390/ ijerph18115515

Academic Editors: Miguel Elias, Maria João Fraqueza, Marta Laranjo and Luís Patarata

Received: 16 April 2021

Accepted: 17 May 2021

Published: 21 May 2021

Publisher's Note: MDPI stays neutral with regard to jurisdictional claims in published maps and institutional affiliations.

Copyright: (c) 2021 by the authors. Licensee MDPI, Basel, Switzerland. This article is an open access article distributed under the terms and conditions of the Creative Commons Attribution (CC BY) license (https:/ / creativecommons.org/licenses/by/ $4.0 /$ )
1 CBQF-Centro de Biotecnologia e Química Fina-Laboratório Associado, Escola Superior de Biotecnologia, Universidade Católica Portuguesa, 4169-005 Porto, Portugal; microhel@gmail.com

2 Colégio de São Gonçalo, 4600-014 Amarante, Portugal; beatriz_silva_22@hotmail.com

3 Colégio Internato dos Carvalhos, 4415-133 Pedroso, Portugal; mhelenocas.almeida@gmail.com

4 Instituto Nacional de Investigação Agrária e Veterinária, I.P., 2780-157 Oeiras and 4485-655 Vairão, Portugal; teresa.nogueira@iniav.pt

5 cE3c-Centre for Ecology, Evolution and Environmental Changes, Faculdade de Ciências da Universidade de Lisboa, 1749-016 Lisboa, Portugal

* Correspondence: jbarbosa@porto.ucp.pt (J.B.); pcteixeira@porto.ucp.pt (P.T.)

+ Both authors contributed equally to this work.

Abstract: Lactiplantibacillus plantarum is one of the lactic acid bacteria species most used as probiotics and starter cultures in food production. Bacteriocin-producers L $p b$. plantarum are also promising natural food preservatives. This study aimed to characterize $L p b$. plantarum $\mathrm{R} 23$ and its bacteriocins (R23 bacteriocins). The genome sequence of $L p b$. plantarum R23 was obtained by whole-genome sequencing (WGS) in an Illumina NovaSeq platform. The activity of $L p b$. plantarum R23-produced bacteriocin against two Listeria monocytogenes strains (L7946 and L7947) was evaluated, and its molecular size was determined by tricine-SDS-PAGE. No virulence or antibiotic resistance genes were detected. Four 100\% identical proteins to the class II bacteriocins (Plantaricin E, Plantaricin F, Pediocin PA-1 (Pediocin AcH), and Coagulin A) were found by WGS analysis. The small $(<6.5 \mathrm{kDa})$ R23 bacteriocins were stable at different $\mathrm{pH}$ values (ranging from 2 to 8), temperatures (between 4 and $100{ }^{\circ} \mathrm{C}$ ), detergents (all, except Triton X-100 and Triton X-114 at $0.01 \mathrm{~g} / \mathrm{mL}$ ), and enzymes (catalase and $\alpha$-amylase), did not adsorb to the producer cells, had a bacteriostatic mode of action and their maximum activity $(\mathrm{AU} / \mathrm{mL}=12,800)$ against two L. monocytogenes strains occurred between 15 and $21 \mathrm{~h}$ of Lpb. plantarum R23 growth. Lactiplantibacillus plantarum R23 showed to be a promising bio-preservative culture because, besides being safe, it produces a stable bacteriocin or bacteriocins (harbors genes encoding for the production of four) inhibiting pathogens as L. monocytogenes. Further studies in different food matrices are required to confirm this hypothesis and its suitability as a future starter culture.

Keywords: bio-preservation; Coagulin A; food safety; pediocin; plantaricin; starter culture

\section{Introduction}

Adequate amounts of ready-to-eat vegetables should be consumed daily as part of a diversified and healthy diet because they are an essential source of vitamins, minerals, dietary fiber, and phytonutrients [1]. Additionally, fresh vegetable consumption also improves gut bacteria diversity, contributing to improved metabolisms [1].

Despite the constant considerable contamination of ready-to-eat vegetables with important foodborne pathogens [2-4], bacteria with benefits for the food industry, such as lactic acid bacteria (LAB), have also been found in these products [5,6]. Lactiplantibacillus plantarum (previously Lactobacillus plantarum) [7] is one of the main promising species of LAB widely used in food production as a probiotic and starter culture [8,9]. Due to their 
long history of safe human use, most of the LAB genera, particularly the Lactiplantibacillus genus, are included in the qualified presumption of safety (QPS) recommendation of the European Food Safety Authority [10]. Their ingestion has been suggested to confer various health benefits, including modulating the immune system, and increasing and improving resistance to malignant and infectious diseases [11,12].

Several LAB were reported to produce a wide range of antimicrobial substances that comprise organic acids, diacetyl, hydrogen peroxide, and bacteriocins [13-15]. The most studied bacteriocins are those produced by LAB, and many of these have shown considerable potential as food preservatives [16] or as therapeutic or bio-controlling agents [17-20]. The added value of their use is due to their non-toxic nature, specific action, physical stability, and high antimicrobial activity [21-24].

In recent years, many bacteriocins have been characterized, but nisin (NisaplinTM) is the only commercially available bacteriocin approved by the Food and Drug Administration [25]. This can be circumvented, because to exert their bioprotective role, bacteriocins can be incorporated into food by using bacteriocin-producing LAB in situ rather than as an ingredient [26].

This study aimed to complement the characterization of a previously isolated bacteriocinproducing Lactiplantibacillus plantarum R23 [15] and its bacteriocins by whole-genome sequencing analysis. This is a useful process to predict the virulent and resistant phenotypes of bacterial strains. Besides its safety and bacteriocin gene identification, the in vitro characterization, mode of action, and stability in different environments of its produced bacteriocin(s) were also evaluated to determine the potential applicability of $\mathrm{Lpb}$. plantarum R23 in the bio-preservation of foods. Despite the long history of several Lpb. plantarum strains as probiotics and starter cultures in the food industry, the continuous isolation and study of new potential strains by the scientific community are significant for the improvement of food safety and, at the same time, to continuously track the interests of the consumers.

\section{Materials and Methods}

\subsection{Origin, Growth, and Storage Conditions of Lactiplantibacillus plantarum R23}

Lactiplantibacillus plantarum R23 was isolated from pre-washed bagged arugula, screened for antimicrobial activity and bacteriocin production, and identified by whole-genome sequencing in our previous publication [15].

This strain was grown aerobically on de Man, Rogosa and Sharpe (MRS) agar and/or broth (Lab M, Bury, UK) at $30{ }^{\circ} \mathrm{C}$ for $24 \mathrm{~h}$ and stored at $-80{ }^{\circ} \mathrm{C}$ in MRS broth (Lab M) containing $30 \%(v / v)$ of glycerol (Sigma, Steinheim, Germany) and sub-cultured twice before use in assays.

\subsection{Whole-Genome Sequencing and Bioinformatic Analyses}

The genome sequence of $L p b$. plantarum R23 was performed by using whole-genome sequencing $(2 \times 150 \mathrm{bp})$ in an Illumina NovaSeq platform. The paired-end fastq files were used to assemble the bacterial genome with the SPAdes genome assembler (version SPAdes-3.12.0-Linux) in a Linux environment [27].

\subsubsection{Virulence and Resistance Profiles of Lpb. plantarum R23}

The ResFinder 4.1 server (accessed on 13 November 2020, at https:/ / cge.cbs.dtu.dk/ services/ResFinder/) [28] was used for predictions of resistance phenotypes from the assembled genome.

A search for the presence of virulence factor determinants was performed by blastx alignment of the sequence contigs against the protein sequences of the core dataset VFDB_setA_pro.fas of the Virulence Factors of Pathogenic Bacteria Database VFDB (accessed on 13 November 2020, at http:/ / www.mgc.ac.cn/cgi-bin/VFs/v5/main.cgi) [29] in a Linux environment, using a filter for E-Values $<10^{-15}$. 


\subsubsection{Identification of $L p b$. plantarum R23-Produced Bacteriocin}

To identify the bacteriocin produced by Lpb. plantarum R23, the fasta file with the generated contigs was used to search for bacteriocins in the core peptide database of bacteriocin classes I, II, and III, on the webserver BAGEL4 (accessed on 13 November 2020, at http:/ /bagel4.molgenrug.nl) [30].

They were also aligned with the BACTIBASE protein fasta file (downloaded on 13 November 2020, at http:/ /bactibase.hammamilab.org/downloads.php), a data repository of natural antimicrobial bacteriocin peptides [31]. The alignment was performed using the blastx tool from the blast (basic local alignment search tool) ncbi-blast-2.10.1 + -1.x86_64.rpm version [32] in a Linux environment, using a filter for E-Values $<10^{-15}$.

\subsection{Characterization of Lpb. plantarum R23-Produced Bacteriocin}

2.3.1. Kinetics of Growth and Bacteriocin Production

An overnight culture was inoculated ( $1 \% v / v$ into $150 \mathrm{~mL}$ of MRS broth) and incubated at $30^{\circ} \mathrm{C}$, without shaking. Samples were taken at regular intervals during $24 \mathrm{~h}$ of incubation. Changes in $\mathrm{pH}$ and optical density $(600 \mathrm{~nm})$ were recorded every hour, and bacteriocin activity (arbitrary unit (AU)/mL) and viable counts were calculated every $3 \mathrm{~h}$, as described by Van Reenen et al. [33]. Listeria monocytogenes strains L7946 and L7947 [34] were used as target organisms. Two independent replicates were performed.

\subsubsection{Effect of Enzymes, Temperature, $\mathrm{pH}$, and Surfactants on Bacteriocin Activity}

Lactiplantibacillus plantarum R23 was grown in MRS broth overnight at $30^{\circ} \mathrm{C}$. Cells were harvested $\left(8000 \times g, 10 \mathrm{~min}, 4^{\circ} \mathrm{C}\right)$, and the cell-free supernatant (CFS) was adjusted to $\mathrm{pH} 6.5$ with $1 \mathrm{M} \mathrm{NaOH}$. One milliliter sterile CFS was incubated for $2 \mathrm{~h}$ in the presence of proteinase $\mathrm{K}$, trypsin, papain, pepsin, $\alpha$-amylase and catalase (all from Boehringer Mannheim $\mathrm{GmbH}$, Mannheim, Germany) at both $1 \mathrm{mg} / \mathrm{mL}$ and $0.1 \mathrm{mg} / \mathrm{mL}$ (final concentrations). The remaining antimicrobial activity was monitored by the agar spot test method. In a separate experiment, $1 \%(w / v)$ sodium dodecyl sulphate (SDS), ethylenediaminetetraacetic (EDTA), Tween 20, Tween 80, urea, Triton X-100, Triton X-114, ox-bile, urea, and $\mathrm{NaCl}$ were added to bacteriocin-containing CFS. EDTA was added to CFS in final concentrations of 1.0, 2.0 and $5.0 \mathrm{mM}$. Untreated CFS and detergents, at the respective concentrations in water, were used as controls. All samples were incubated at $30^{\circ} \mathrm{C}$ for $5 \mathrm{~h}$ and then tested for antimicrobial activity. The effect of $\mathrm{pH}$ on bacteriocin activity was tested by adjusting the $\mathrm{pH}$ of sterile CFS from 2.0 to 12.0 (at increments of two $\mathrm{pH}$ units) with sterile $1 \mathrm{M} \mathrm{NaOH}$ or $1 \mathrm{M} \mathrm{HCl}$. After $1 \mathrm{~h}$ of incubation at room temperature $\left(25^{\circ} \mathrm{C}\right)$, samples were readjusted to $\mathrm{pH} 6.5$ with sterile $1 \mathrm{M} \mathrm{NaOH}$ or $1 \mathrm{M} \mathrm{HCl}$, heated to $80^{\circ} \mathrm{C}$ for $10 \mathrm{~min}$, and tested for antimicrobial activity. The effect of temperature on bacteriocin activity was tested by incubating CFS at $4,25,30,37,45,60,80$, and $100{ }^{\circ} \mathrm{C}$ for $120 \mathrm{~min}$. Bacteriocin activity was also tested after $15 \mathrm{~min}$ at $121^{\circ} \mathrm{C}$. The agar spot test method for the antimicrobial activity [33] was used in all experiments. Listeria monocytogenes strains L7946 and L7947 served as target strains.

\subsubsection{Cell Lysis}

Twenty milliliters of the bacteriocin-containing cell-free supernatant $(12,800 \mathrm{AU} / \mathrm{mL}$, pH 6.0 assayed on L. monocytogenes L7946 and L. monocytogenes L7947) was filter-sterilized and added to $100 \mathrm{~mL}$ early exponential phase $(5 \mathrm{~h}$ old; $\mathrm{OD}=0.6)$ cultures of L. monocytogenes L7946 and L7947. Optical density readings at $600 \mathrm{~nm}$ were taken every hour for $13 \mathrm{~h}$. Both L. monocytogenes cultures without added bacteriocins were used as controls, and two independent replicates were performed. 


\subsubsection{Adsorption Studies}

Adsorption of bacteriocin to producer cells was studied according to the method described by Yang et al. [35]. Lactiplantibacillus plantarum R23 was cultured for $18 \mathrm{~h}$ at $30^{\circ} \mathrm{C}$. The $\mathrm{pH}$ of the culture was adjusted to 6.0 with $1 \mathrm{M} \mathrm{NaOH}$ to allow maximal adsorption of the bacteriocin to the producer cells. The cells were then harvested $\left(12,000 \times \mathrm{g}, 15 \mathrm{~min}, 4^{\circ} \mathrm{C}\right)$ and washed with sterile $0.1 \mathrm{M}$ phosphate buffer ( $\mathrm{pH}$ 6.5). The pellet was re-suspended in $10 \mathrm{~mL} 100 \mathrm{mM} \mathrm{NaCl}(\mathrm{pH} 2.0)$ and agitated for $1 \mathrm{~h}$ at $4{ }^{\circ} \mathrm{C}$ to allow delaminating bacteriocin from the cells. The cells were then harvested $\left(12,000 \times \mathrm{g}, 15 \mathrm{~min}, 4^{\circ} \mathrm{C}\right)$, the cell-free supernatant neutralized to $\mathrm{pH} 7.0$ with sterile $1 \mathrm{M} \mathrm{NaOH}$, and was then tested for bacteriocin activity, as described by Van Reenen et al. [33].

\subsubsection{Partial Purification and Molecular Size}

After $18 \mathrm{~h}$ growth of the $\mathrm{Lpb}$. plantarum R23 culture, the supernatant resulting from the first centrifugation $\left(12,000 \times g, 20 \mathrm{~min}, 4^{\circ} \mathrm{C}\right)$ was kept at $4{ }^{\circ} \mathrm{C}$ for partial purification. Ammonium sulphate was added gradually to the stored supernatant to reach $40 \%, 60 \%$, and $80 \%$ of saturation, in independent experiments, and each solution was kept at slow stirring for $4 \mathrm{~h}$ at $4{ }^{\circ} \mathrm{C}$. After centrifugation $\left(12,000 \mathrm{rpm}, 20 \mathrm{~min}, 4^{\circ} \mathrm{C}\right)$, precipitated proteins in the pellet and floating on the surface were collected and dissolved in $25 \mathrm{mM}$ ammonium acetate buffer ( $\mathrm{pH}$ 6.5), following the method described by Sambrook et al. [36]. All samples were stored at $-20^{\circ} \mathrm{C}$.

To determine the bacteriocin molecular size, samples were separated by tricine-SDSPAGE according to Schägger and Von Jagow [37]. A low molecular weight marker with sizes ranging from $6.5 \mathrm{kDa}$ to $270 \mathrm{kDa}$ (GRS Protein Marker MultiColour PLUS; Grisp, Porto, Portugal) was used. After running, the gel was split in two. One half was fixed with $20 \%$ isopropanol and $10 \%$ acetic acid, and the other half was stained with Coomassie Brilliant Blue R250 (Bio-Rad, Hercules, CA, USA) to visualize the position of the peptide band. The position of the active bacteriocin was determined by overlaying the half of the unstained-gel, and extensively pre-washed with the sterile distilled water, with cells of L. monocytogenes L7946 (106 colony-forming units (CFU)/mL), firstly embedded in brain heart infusion (BHI; Biokar, Beauvais, France) soft agar $(0.7 \%$ agar $w / v)$.

\section{Results}

\subsection{Characterization of Lpb. plantarum R23 by Whole-Genome Sequencing}

\subsubsection{Presence of Antibiotic Resistances}

No antibiotic resistance phenotype could be predicted from the analysis of the contigs of $L p b$. plantarum R23, because the ResFinder 4.1 software could not detect any homologue of genes encoding antibiotic resistance.

\subsubsection{Presence of Virulence Factors}

No significant blastx alignments ( $E$ value $<10^{-15}$ and $60 \%$ of alignment coverage) were detected between the translated DNA sequences of the assembled contigs and the database of pathogenic bacteria virulence factors, such as proteins engaged in adhesion and invasion, secretion systems and its effectors, toxins, and iron acquisition by the bacterial cell.

\subsection{Identification of Lpb. plantarum R23 Bacteriocin by Whole-Genome Sequencing}

The BAGEL4 software showed that a contig of the assembled bacterial genome encodes two proteins that are $100 \%$ identical to the class II bacteriocins, Plantaricin E and Plantaricin $\mathrm{F}$, both from the bacterium Lpb. plantarum (Figure 1A). Upstream of the genes encoding plantaricins, and in the same operon, two lanT gene homologues encoded the bacteriocin $\mathrm{ABC}$ transporter, the ATP binding protein, and the permease protein PlnG. 
The sequence of another contig showed $100 \%$ identity with the pediocin proteins (Figure 1B) of the Pediococcus acidilactici organism. In the same operon, located downstream was the LanT gene that encoded the transport-processing Pediocin PA-1 of the ATP-binding protein PedD and an open reading frame (ORF) that encoded the pediocin biosynthesis protein PA-1 P. This operon also included a gene encoding a Leucocin A homologue.

These results were confirmed by the alignment of blastx against BACTIBASE, a database of bacterial antimicrobial peptides. Significant alignments confirmed the presence of the following protein homologues: Plantaricin F in a contig; Pediocin PA-1 (Pediocin $\mathrm{ACH})$, and Coagulin $\mathrm{A}$ in the other.

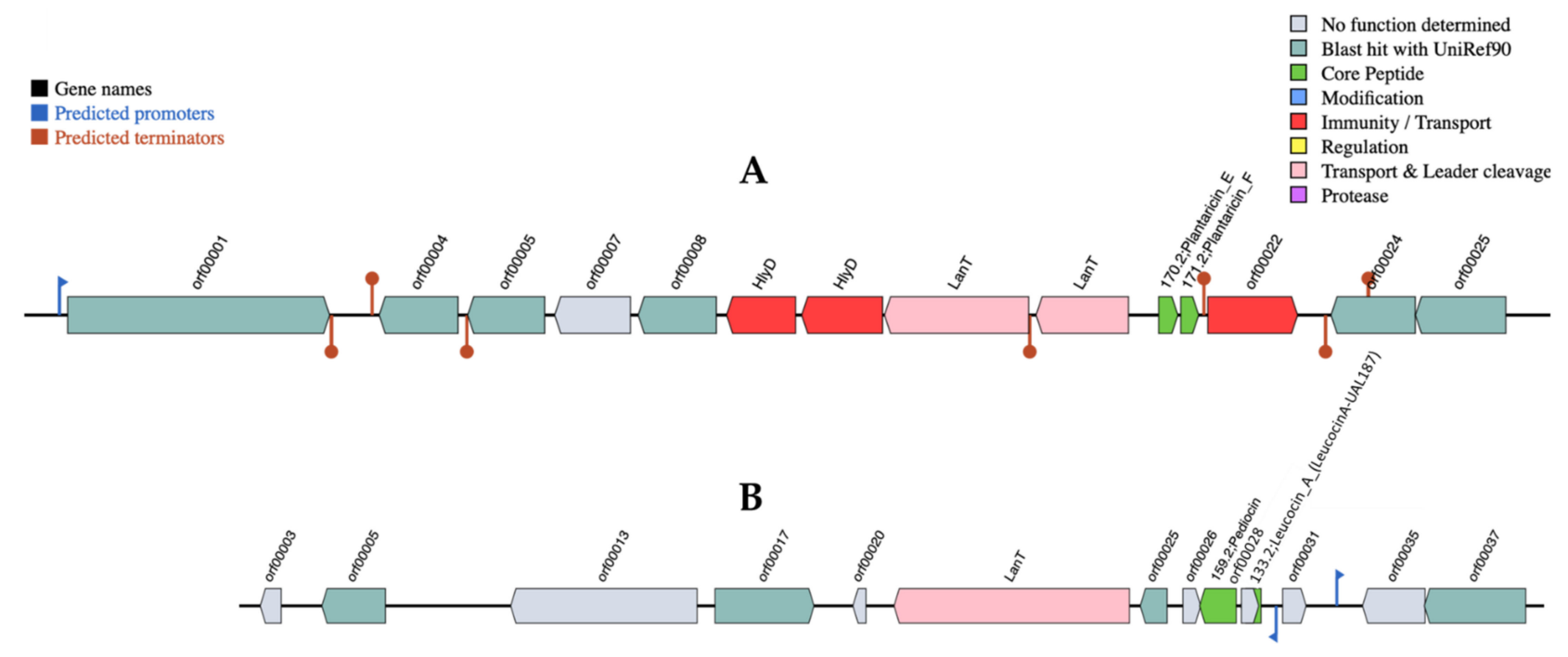

Figure 1. Genetic organization map of the plantaricins (A) and pediocin (B) gene clusters of the Lpb. plantarum R23 strain.

\subsection{Characterization of Lpb. plantarum R23-Produced Bacteriocin}

Based on WGS, Lpb. plantarum R23 may produce more than one bacteriocin. All the experiments characterizing R23 bacteriocin were performed using the crude supernatant; therefore, the results presented in the following sections may refer to one or more bacteriocins.

\subsubsection{Kinetics of Growth and Bacteriocin Production}

The bacteriocin(s) activity in AU/mL produced by Lpb. plantarum $\mathrm{R} 23$ against the two Listeria strains over time is shown in Figure 2. It is possible to conclude that the bacteriocin(s) showed maximum activity between 15 and $21 \mathrm{~h}(\mathrm{AU} / \mathrm{mL}=12,800)$. The $\mathrm{pH}$ value started to decrease from $6 \mathrm{~h}$ and stabilized after $15 \mathrm{~h}$. 


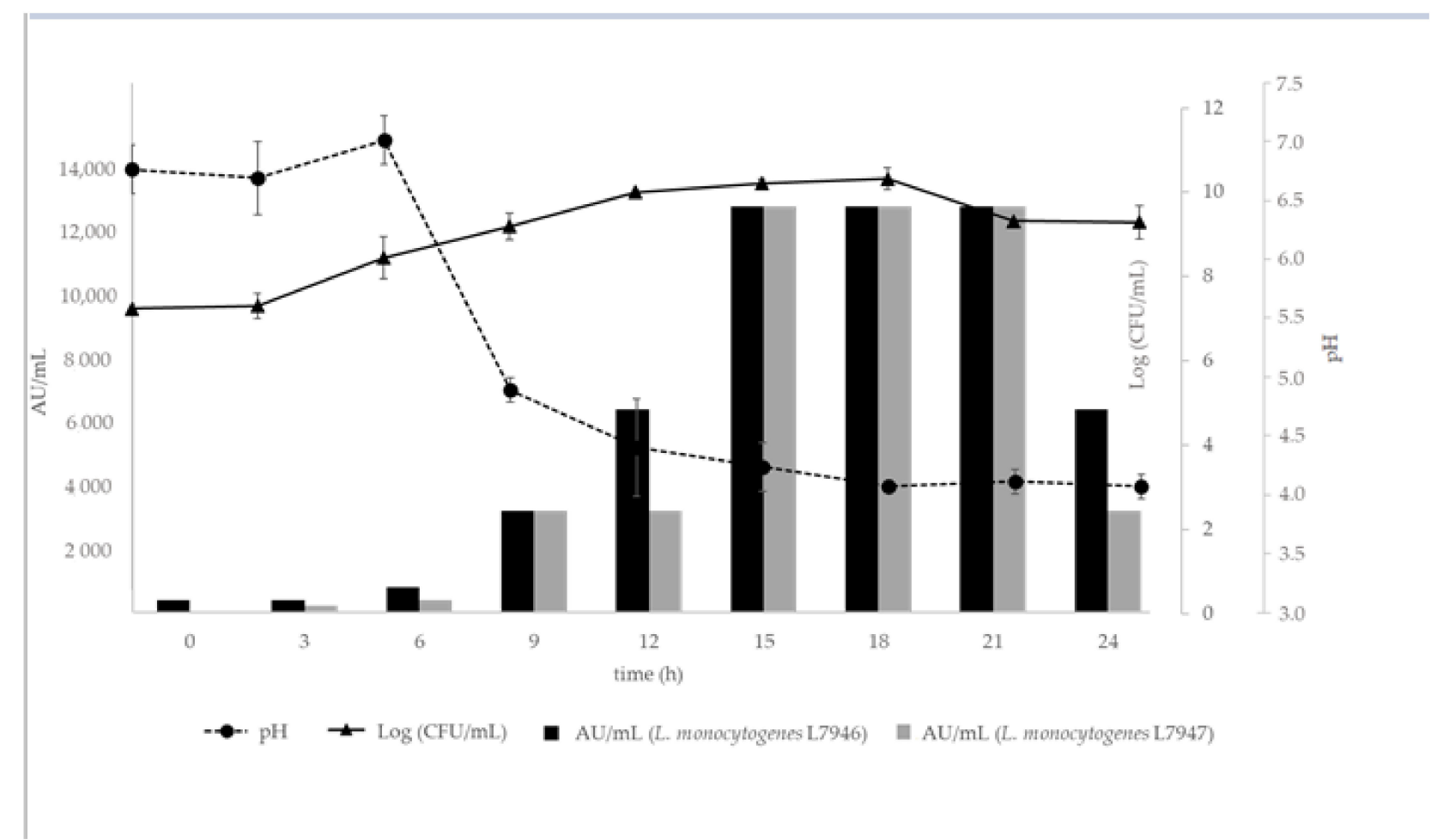

Figure 2. Production of bacteriocin(s) by Lpb. plantarum R23 in MRS broth (pH 6.4) at $30^{\circ} \mathrm{C}$. The antimicrobial activity of cell-free supernatants is presented as AU/mL (bars) for L. monocytogenes L7946 and L7947 strains.

\subsubsection{Effect of Enzymes, Temperature, $\mathrm{pH}$, and Surfactants on Bacteriocin(s) Activity}

The impact of certain detergents, enzymes, $\mathrm{pH}$, and temperature values on bacteriocin(s) activity against L. monocytogenes L7946 and L7947 are shown in Table 1.

The bacteriocin(s) was resistant to most detergents because the reduction in its activity was negligible. For the enzymes tested, only papain and catalase did not decrease bacteriocin(s) activity, while trypsin and proteinase K reduced bacteriocinogenic activity by $100 \%$. As for the $\mathrm{pH}$ values, it was possible to verify that the bacteriocin(s) was quite resistant to a wide range of values (between 2 and 8 ). The same was verified regarding the tested temperatures, with a marked decrease in bacteriocin(s) activity only at $121^{\circ} \mathrm{C}$.

Table 1. Effect of different treatments on bacteriocin(s) activity against the target organisms $L$. monocytogenes L7946 and L. monocytogenes L7947, expressed in corresponding percentage values (\%) of reduction.

\begin{tabular}{|c|c|c|c|}
\hline & & L. monocytogenes L7946 & L. monocytogenes L7947 \\
\hline \multirow{6}{*}{$\mathrm{pH}$} & 2 & $1.6 \%$ & $1.6 \%$ \\
\hline & 4 & $0.0 \%$ & $0.0 \%$ \\
\hline & 6 & $0.0 \%$ & $0.0 \%$ \\
\hline & 8 & $1.6 \%$ & $1.6 \%$ \\
\hline & 10 & $12.5 \%$ & $12.5 \%$ \\
\hline & 12 & $100.0 \%$ & $100.0 \%$ \\
\hline \multirow{8}{*}{$\begin{array}{c}\text { Temperature } \\
\left({ }^{\circ} \mathrm{C}\right)\end{array}$} & 4 & $3.1 \%$ & $3.1 \%$ \\
\hline & 25 & $1.6 \%$ & $1.6 \%$ \\
\hline & 30 and 37 & $0.0 \%$ & $0.0 \%$ \\
\hline & 45 & $3.1 \%$ & $6.3 \%$ \\
\hline & 60 & $3.1 \%$ & $6.3 \%$ \\
\hline & 80 & $6.3 \%$ & $6.3 \%$ \\
\hline & 100 & $12.5 \%$ & $12.5 \%$ \\
\hline & 121 & $100.0 \%$ & $100.0 \%$ \\
\hline
\end{tabular}


Table 1. Cont.

\begin{tabular}{|c|c|c|c|}
\hline & & L. monocytogenes L7946 & L. monocytogenes L7947 \\
\hline \multirow{9}{*}{$\begin{array}{l}\text { Enzymes } \\
(\mathrm{mg} / \mathrm{mL})\end{array}$} & Proteinase $\mathrm{K}_{1.0 \mathrm{and} 0.1}$ & $100.0 \%$ & $100.0 \%$ \\
\hline & Papain $_{1.0}$ & $50.0 \%$ & $50.0 \%$ \\
\hline & Papain $_{0.1}$ & $50.0 \%$ & $50.0 \%$ \\
\hline & Pepsin $_{1.0}$ & $100.0 \%$ & $100.0 \%$ \\
\hline & Pepsin 0 & $50.0 \%$ & $25.0 \%$ \\
\hline & Trypsin $_{1.0 \text { and } 0.1}$ & $100.0 \%$ & $100.0 \%$ \\
\hline & $\alpha$-amylase 1.0 & $6.3 \%$ & $25.0 \%$ \\
\hline & $\alpha$-amylase 0.1 & $0.0 \%$ & $0.0 \%$ \\
\hline & Catalase $_{1.0 a n d 0.1}$ & $0.0 \%$ & $0.0 \%$ \\
\hline \multirow{8}{*}{ Detergents } & Tween 20 and Tween $80_{0.01 \mathrm{~g} / \mathrm{mL}}$ & $3.1 \%$ & $3.1 \%$ \\
\hline & $\begin{array}{c}\text { Triton X-114 and Triton } \\
\text { X-100 }\end{array}$ & $50.0 \%$ & $50.0 \%$ \\
\hline & $\mathrm{SDS}_{0.01 \mathrm{~g} / \mathrm{mL}}$ & $0.0 \%$ & $1.6 \%$ \\
\hline & $\mathrm{EDTA}_{0.1 \mathrm{mM}}$ & $3.1 \%$ & $3.1 \%$ \\
\hline & $\mathrm{EDTA}_{2.0 \mathrm{mM}}$ & $3.1 \%$ & $3.1 \%$ \\
\hline & EDTA $_{5.0 \mathrm{mM}}$ & $6.3 \%$ & $6.3 \%$ \\
\hline & Ox-bile $0.01 \mathrm{~g} / \mathrm{mL}$ & $1.6 \%$ & $1.6 \%$ \\
\hline & Urea and $\mathrm{NaCl}_{0.01 \mathrm{~g} / \mathrm{mL}}$ & $0.0 \%$ & $0.0 \%$ \\
\hline
\end{tabular}

Note: Without treatment, the maximum activity of R23 bacteriocin(s) for each L. monocytogenes strain was $12,800 \mathrm{AU} / \mathrm{mL}$. The percentage values of inhibition are represented according to this maximum activity.

\subsubsection{Cell Lysis}

The inhibitory effect of $L p b$. plantarum R23 bacteriocin(s) produced over time and the type of pathogen used is shown in Figure 3. It was found that after the addition of the bacteriocin-containing cell-free supernatant to the pathogen at the beginning of the exponential phase (after $5 \mathrm{~h}$ of growth), its growth was inhibited.

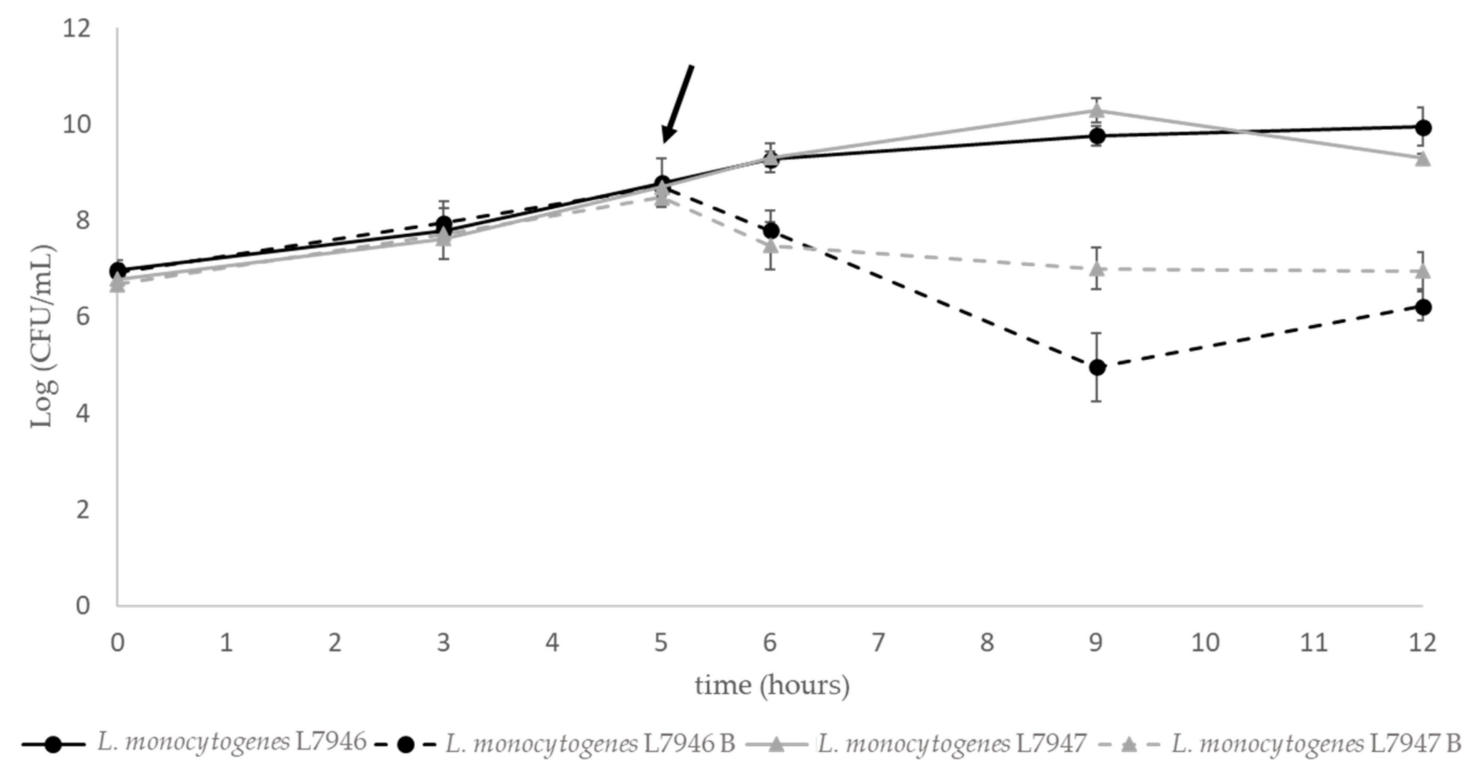

Figure 3. Effect of R23 bacteriocin(s) on the growth of L. monocytogenes L9746 (dotted black lines) and L. monocytogenes L7947 (dotted grey lines) presented as $\log (\mathrm{CFU} / \mathrm{mL})$. The continuous line represents target cultures without added bacteriocins. The arrow indicates the point at which the bacteriocin-containing CFS was added.

\subsubsection{Adsorption Studies and Molecular Size}

The bacteriocin(s) did not adhere to the surface of the producer cells, because its activity was not detected $(0 \mathrm{AU} / \mathrm{mL})$ after the treatment of $L p b$. plantarum R23 with $100 \mathrm{mM} \mathrm{NaCl}$ at $\mathrm{pH}$ 2.0.

The approximate molecular size of this bacteriocin was below $6.5 \mathrm{kDa}$ (data not shown). When the gel with the peptide band was overlaid with cells of L. monocytogenes L7946 
already embedded in BHI soft agar, the position of the active bacteriocin was observed by a zone of growth inhibition, which was coincident with the position of the active bacteriocin in the molecular mass marker.

\section{Discussion}

Lactiplantibacillus plantarum R23 was isolated from arugula and was first screened for bacteriocin production and probiotic potential in one of our previous studies [15]. In the absence of a protector food matrix, this strain could not survive through the simulated digestion, making its probiotic potential unfeasible. However, this strain's ability to produce a bacteriocin with activity against deteriorating and pathogenic microorganisms (Bacillus subtilis, Enterococcus faecalis, Listeria innocua, and L. monocytogenes) is a great advantage that should not be ignored. Thus, this study arose intending to study the characteristics of the Lpb. plantarum R23 strain and its produced bacteriocin(s) to ascertain its potential to be used in the food industry as a bio-preservative or starter culture.

The results from the analysis of Lpb. plantarum R23 contigs may suggest that this genome does not contain any antibiotic resistance genes. However, because the assembled genome is not closed, the presence of any antibiotic-resistant gene encoded in any uncovered region of the bacterial genome cannot be excluded. On the other hand, resistance may also result from changes/mutations in some genes codifying proteins involved in resistance, an aspect that was not addressed during this study. Nevertheless, in our previous study [15], it had already been proven that the Lpb. plantarum R23 was inhibited by the established antibiotics at concentrations equal to or lower than the cut-off values defined by the Panel on Additives and Products or Substances in Animal Feed (FEEDAP) of the EFSA [38]. Both phenotypic susceptibility and the absence of transferable antimicrobial resistance genes suggest that $L p b$. plantarum $\mathrm{R} 23$ is considered acceptable to be used as a feed additive [38].

Despite some genes encoding virulence factors possibly being located in an unsequenced region of the genome, the absence of detectable virulence factors from the assembled contigs suggests that Lpb. plantarum R23 does not have classical virulence factors. This is also corroborated by its phenotypic and genotypic characterization in our previous study; biogenic amines, hemolysis, gelatinase, and DNase were not produced by this strain, and virulence determinants screened by PCR assays were not detected [15].

Several authors have reported the isolation of other $L p b$. plantarum strains from various foods and their safety due to the absence of acquired antibiotic resistance genes $[39,40]$ and virulence factors $[39,41]$. The identification and characterization of Lpb. plantarum R23 by whole-genome sequencing confirms the results previously obtained during the characterization of this bacterium [15]. These characteristics indicate that Lpb. plantarum R23 may be considered a safe culture to be used in the food industry. According to a report published by the EFSA [42], the whole-genome sequencing analysis should be performed for all the strains intentionally used in the food chain, because it can provide unequivocal information regarding their taxonomic identification and their potential virulence factors and resistance to antibiotics of clinical relevance.

As previously mentioned, $L p b$. plantarum R23 demonstrated antimicrobial activity due to its bacteriocinogenic activity against Gram-positive pathogens and spoilage bacteria [15] From the whole-genome sequencing analysis, two $100 \%$ identical proteins to the class II bacteriocins-Plantaricin E and Plantaricin F-were found (Figure 1A). Plantaricin E is a bacteriocin precursor of the PlnE peptide [43], and the other ORFs of this operon share homology with $p \ln D, p \ln G, p \ln H$ and $p \ln S$, suggesting that they belong to a $p \ln$ operon, such as the one involved in the production of bacteriocin from Lpb. plantarum [44]. Besides plantaricin, the other contigs Pediocin PA-1 (Pediocin AcH) and Coagulin A (Figure 1B) were also found to share $100 \%$ identity with the Pediocin proteins. Coagulins are anti-listeria bacteriocins belonging to the Pediocin family [45].

Plantaricins and Pediocins belong to a class II bacteriocins, a large group of small $(<10 \mathrm{kDa})$, heat-stable, and non-lantibiotic peptides [46]. Pediocin PA-/AcH is one of the 
most studied class II bacteriocin and its production by different $L p b$. plantarum strains has already been reported $[47,48]$. Additionally, several plantaricins produced by several $L p b$. plantarum strains have been found and characterized [49-52].

The bacteriocin(s) produced by Lpb. plantarum R23 was semi-purified and characterized in this study. It is important to highlight that the R23 bacteriocin(s) characterization was performed using the crude supernatant, thus it will be necessary to further purify and identify the peptide(s).

To elucidate the time of incubation at which $\mathrm{Lpb}$. plantarum R23 exhibited the maximum bacteriocin(s) production, the profiles of the growth kinetics and bacteriocin(s) activity in $\mathrm{AU} / \mathrm{mL}$ against two Listeria strains over time were determined (Figure 2). The decrease in $\mathrm{pH}$ values over time (after $6 \mathrm{~h}$ and stabilization after $15 \mathrm{~h}$ ) is due to the lactic acid produced by $\mathrm{Lpb}$. plantarum $\mathrm{R} 23$. The maximum bacteriocin(s) activity $(\mathrm{AU} / \mathrm{mL}=12,800)$ occurred between 15 and $21 \mathrm{~h}$ of Lpb. plantarum R23 growth, which is in accordance with what has been reported by other authors $[53,54]$. The supernatant of the Lpb. plantarum $\mathrm{R} 23$ cultured for $18 \mathrm{~h}$ was therefore used for subsequent experiments. The bacteriocin(s) production in the early stages of $L p b$. plantarum R23 growth cycle is a considerable advantage when competitive growth is desired or for the inhibition of pathogens before reaching their exponential growth phase.

The stability of the bacteriocin(s) against two L. monocytogenes strains when exposed to different treatments with enzymes, temperatures, $\mathrm{pH}$ values, and surfactants was evaluated (Table 1).

The antimicrobial activity of the bacteriocin(s) produced by Lpb. plantarum R23 was affected (12.5-100\% reduction) at $\mathrm{pH}$ values above 8 . At $\mathrm{pH}$ values of 2 and 8 , the reductions were very low $(1.56 \%)$. This suggests that this bacteriocin(s) is sensitive to alkaline environments, as already verified for other $\mathrm{Lpb}$. plantarum-produced bacteriocins $[55,56]$.

The bacteriocin(s) activity was maintained at temperatures between 4 and $100{ }^{\circ} \mathrm{C}$, which corroborates its thermo-stability, one of the characteristics of bacteriocins belonging to class II bacteriocins. Negligible reductions were observed below $30^{\circ} \mathrm{C}$ and above $37^{\circ} \mathrm{C}$, and no activity ( $100 \%$ of reduction) was only observed at $121^{\circ} \mathrm{C}$. Similar results were also obtained for other bacteriocins produced by different $L p b$. plantarum strains [56,57].

A slight reduction in bacteriocin activity(s) was observed for most detergents tested, except for Triton X-100 and Triton X-114 at $0.01 \mathrm{~g} / \mathrm{mL}$ (50\% reduction). Only for catalase and $\alpha$-amylase enzymes was the bacteriocin activity not fully reduced, confirming its proteinaceous nature. Other authors have already reported similar bacteriocin stabilities after the treatment of the same detergents and/or enzymes [53,56,58].

Another important feature is the effect of the bacteriocin on the target microorganism's growth, evaluating their potential cell lysis. When the supernatant of Lpb. plantarum R23 was added to a $5 \mathrm{~h}$ old culture of L. monocytogenes (early exponential phase), decreases of about two log cycles were observed for both target strains (Figure 3). However, after $9 \mathrm{~h}$ and until $12 \mathrm{~h}$ of incubation, a slow growth of both L. monocytogenes strains was observed. Apparently, the bacteriocin(s) had an effect on the pathogen viability at the moment of addition, but were reduced over time. This means that bacteriocin(s) produced by $L p b$. plantarum R23 had a bacteriostatic mode of action. Although a vast number of $L p b$. plantarum produced bacteriocins with bactericidal effect $[56,59,60]$, a similar bacteriostatic effect has been reported for other bacteriocins [61-63].

Bacteriocin(s) produced by Lpb. plantarum R23 did not adsorb to the producer cells, because its activity was not detected after treatment of $L p b$. plantarum R23 with $100 \mathrm{mM}$ $\mathrm{NaCl}$ at $\mathrm{pH}$ 2.0. Similar observations were also recorded for Plantaricin ST31 [64] and Pediocin ST194BZ [65].

Finally, as expected, the molecular size of the $\mathrm{Lpb}$. plantarum $\mathrm{R} 23$ bacteriocin(s) was below $6.5 \mathrm{kDa}$, as determined by tricine-SDS-PAGE (Figure S1). This is in agreement with the identification obtained by whole-genome sequencing because plantaricins and pediocins are small peptides $(<10 \mathrm{kDa})$ belonging to class II bacteriocins. This molecular size is also within the range of most bacteriocins reported for other $L p b$. plantarum strains $[53,66,67]$. 


\section{Conclusions}

From both phenotypic characterization and whole-genome sequencing analysis, $\mathrm{Lpb}$. plantarum R23 may be considered a safe culture to be used in the food industry. Additionally, this bacterium produces a stable bacteriocin which, besides being safe, makes it a potential bio-preservative culture inhibiting pathogens such as L. monocytogenes and spoilage bacteria to guarantee the safety and the extension of food shelf life. Once Lpb. plantarum R23 harbors genes encoding for the production of Plantaricin E, Plantaricin F, Pediocin PA-1 (Pediocin $\mathrm{AcH}$ ), and Coagulin $\mathrm{A}$, recognition of the conditions in which more than one bacteriocin, or even all, are produced is mandatory to increase knowledge about $L p b$. plantarum R23 applicability.

After the preliminary characterization of $\mathrm{Lpb}$. plantarum R23, it is possible to conclude that it is a relevant strain with promising characteristics, which should be studied more deeply to evaluate its potential future use in the food industry as a bio-protective or starter culture.

Supplementary Materials: The following are available online at https://www.mdpi.com/article/10 .3390/ijerph18115515/s1. Figure S1: Tricine-SDS Page of Bacteriocin(s) produced by Lpb. plantarum R23. Legend: Lanes 1 to 3: peptide bands stained with Coomassie Blue R250 with $40 \%$ saturated ammonium sulfate (lane 1); 60\% saturated ammonium sulfate (lane 2); 80\% saturated ammonium sulfate (lane 3); lane 4: molecular mass marker; lane 5: zone of growth inhibition, corresponding to the position of the peptide bands in lane 1; lane 6: zone of growth inhibition, corresponding to the position of the peptide bands in lane 2 and lane 7: zone of growth inhibition, corresponding to the position of the peptide bands in lane 3.

Author Contributions: Conceptualization, J.B., H.A.; P.T.; formal analysis, J.B., H.A., T.N., P.T.; investigation, J.B., H.A., B.S., M.H.A.; resources, P.T.; writing—original draft preparation, J.B., H.A., T.N.; writing—review and editing, J.B., H.A., T.N., P.T.; supervision, J.B., H.A., P.T.; funding acquisition, P.T. All authors have read and agreed to the published version of the manuscript.

Funding: This research received no external funding.

Institutional Review Board Statement: Not applicable.

Informed Consent Statement: Not applicable.

Data Availability Statement: Not applicable.

Acknowledgments: The authors would like to thank the scientific collaboration under the Fundação para a Ciência e a Tecnologia (FCT) project UIDP/00329/2020. Financial support for author J. Barbosa was provided by a post-doctoral fellowship SFRH/BPD/113303/2015 (FCT), and T. Nogueira by contract ALG-01-0145-FEDER-028824/PTDC/BIA-MIC/28824/2017 (FCT). The authors are grateful to Fernanda Simões for granting access to the INIAV's bioinformatic server.

Conflicts of Interest: The authors declare no conflict of interest.

\section{References}

1. Food and Agriculture Organization. Fruit and Vegetables_Your Dietary Essentials; The International Year of Fruits and Vegetables, 2021, background paper; Food and Agriculture Organization: Rome, Italy, 2020. [CrossRef]

2. Emilse, P.V.; Matías, V.; Cecilia, M.L.; Oscar, G.M.; Gisela, M.; Guadalupe, D.; Elizabeth, R.V.; Victorio, P.J.; Rodney, C.; Viviana, N.S.; et al. Enteric virus presence in green vegetables and associated irrigation waters in a rural area from Argentina. A quantitative microbial risk assessment. LWT 2021, 144, 111201. [CrossRef]

3. Xylia, P.; Botsaris, G.; Chrysargyris, A.; Skandamis, P.; Tzortzakis, N. Variation of microbial load and biochemical activity of ready-to-eat salads in Cyprus as affected by vegetable type, season, and producer. Food Microbiol. 2019, 83, 200-210. [CrossRef]

4. Park, S.; Szonyi, B.; Gautam, R.; Nightingale, K.; Anciso, J.; Ivanek, R. Risk factors for microbial contamination in fruits and vegetables at the preharvest level: A systematic review. J. Food Prot. 2012, 75, 2055-2081. [CrossRef]

5. Trias, R.; Bañeras, L.; Badosa, E.; Montesinos, E. Bioprotection of Golden Delicious apples and Iceberg lettuce against foodborne bacterial pathogens by lactic acid bacteria. Int. J. Food Microbiol. 2008, 123, 50-60. [CrossRef] [PubMed]

6. Fessard, A.; Remize, F. Genetic and technological characterization of lactic acid bacteria isolated from tropically grown fruits and vegetables. Int. J. Food Microbiol. 2019, 301, 61-72. [CrossRef] 
7. Zheng, J.; Wittouck, S.; Salvetti, E.; Franz, C.M.A.P.; Harris, H.M.B.; Mattarelli, P.; O’Toole, P.W.; Pot, B.; Vandamme, P.; Walter, J.; et al. A taxonomic note on the genus Lactobacillus: Description of 23 novel genera, emended description of the genus Lactobacillus Beijerinck 1901, and union of Lactobacillaceae and Leuconostocaceae. Int. J. Syst. Evol. Microbiol. 2020, 70, 2782-2858. [CrossRef]

8. Tosukhowong, A.; Visessanguan, W.; Pumpuang, L.; Tepkasikul, P.; Panya, A.; Valyasevi, R. Biogenic amine formation in Nham, a Thai fermented sausage, and the reduction by commercial starter culture, Lactobacillus plantarum BCC 9546. Food Chem. 2011, 129, 846-853. [CrossRef] [PubMed]

9. Arena, M.P.; Silvain, A.; Normanno, G.; Grieco, F.; Drider, D.; Spano, G. Use of Lactobacillus plantarum strains as a bio-control strategy against food-borne pathogenic microorganisms. Front. Microbiol. 2016, 7, 464. [CrossRef]

10. European Food Safety Authority. Update of the list of QPS-recommended biological agents intentionally added to food or feed as notified to EFSA 10: Suitability of taxonomic units notified to EFSA until March 2019. EFSA J. 2019, 17, 5753. [CrossRef]

11. Soccol, C.R.; Vandenberghe, L.P.S.; Spier, M.R.; Medeiros, A.B.P.; Yamaguishi, C.T.; Lindner, J.D.D.; Pandey, A.; Thomaz-Soccol, V. The potential of probiotics: A review. Food Technol. Biotechnol. 2010, 48, 413-434.

12. Kim, S.-K.; Guevarra, R.B.; Kim, Y.-T.; Kwon, J.; Kim, H.; Cho, J.H.; Kim, H.B.; Lee, J.-H. Role of probiotics in human gut microbiome-associated diseases. J. Microbiol. Biotechnol. 2019, 29, 1335-1340. [CrossRef] [PubMed]

13. Galvez, A.; Abriouel, H.; Lopez, R.L.; Ben Omar, N. Bacteriocin-based strategies for food biopreservation. Int. J. Food Microbiol. 2007, 120, 51-70. [PubMed]

14. Kavitha, S.; Harikrishnan, A.; Jeevaratnam, K. Characterization and evaluation of antibacterial efficacy of a novel antibiotic-type compound from a probiotic strain Lactobacillus plantarum KJB23 against food-borne pathogens. LWT 2020, 118, 108759. [CrossRef]

15. Pinto, A.; Barbosa, J.; Albano, H.; Isidro, J.; Teixeira, P. Screening of bacteriocinogenic lactic acid bacteria cultures and their characterization as potential probiotics. Microorganisms 2020, 8, 393. [CrossRef] [PubMed]

16. Daba, G.M.; Elkhateeb, W.A. Bacteriocins of lactic acid bacteria as biotechnological tools in food and pharmaceuticals: Current applications and future prospects. Biocatal. Agric. Biotechnol. 2020, 28, 101750. [CrossRef]

17. Zhao, S.; Han, J.; Bie, X.; Lu, Z.; Zhang, C.; Lv, F. Purification and characterization of plantaricin JLA-9: A novel bacteriocin against Bacillus spp. produced by Lactobacillus plantarum JLA-9 from Suan-Tsai, a traditional Chinese fermented cabbage. J. Agric. Food Chem. 2016, 64, 2754-2764. [CrossRef]

18. Hwanhlem, N.; Ivanova, T.; Biscola, V.; Choiset, Y.; Haertlé, T. Bacteriocin producing Enterococcus faecalis isolated from chicken gastrointestinal tract originating from Phitsanulok, Thailand: Isolation, screening, safety evaluation and probiotic properties. Food Control 2017, 78, 187-195. [CrossRef]

19. Qiao, Z.; Sun, H.; Zhou, Q.; Yi, L.; Wang, X.; Shan, Y.; Yi, Y.; Liu, B.; Zhou, Y.; Lü, X. Characterization and antibacterial action mode of bacteriocin BMP32r and its application as antimicrobial agent for the therapy of multidrug-resistant bacterial infection. Int. J. Biol. Macromol. 2020, 164, 845-854. [CrossRef]

20. Balmeh, N.; Mahmoudi, S.; Fard, N.A. Manipulated bio antimicrobial peptides from probiotic bacteria as proposed drugs for COVID-19 disease. Inform. Med. Unlocked 2021, 23, 100515. [CrossRef] [PubMed]

21. Abrams, D.; Barbosa, J.; Albano, H.; Silva, J.; Gibbs, P.A.; Teixeira, P. Characterization of bacPPK34 a bacteriocin produced by Pediococcus pentosaceus strain K34 isolated from "Alheira". Food Control 2011, 22, 940-946. [CrossRef]

22. Martinez, R.C.R.; Staliano, C.D.; Vieira, A.D.S.; Villarreal, M.L.M.; Todorov, S.D.; Saad, S.M.I.; Franco, B.D.G.M. Bacteriocin production and inhibition of Listeria monocytogenes by Lactobacillus sakei subsp sakei 2a in a potentially synbiotic cheese spread. Food Microbiol. 2015, 48, 43-152. [CrossRef] [PubMed]

23. Ahn, H.; Kim, J.; Kim, W.J. Isolation and characterization of bacteriocin-producing Pediococcus acidilactici HW01 from malt and its potential to control beer spoilage lactic acid bacteria. Food Control 2017, 80, 59-66. [CrossRef]

24. Oliveira, M.; Barbosa, J.; Albano, H.; Teixeira, P. Bacteriocinogenic activity of Leuconostoc lactis RK18 isolated from fermented food. In Fermented Foods: Nutrition and Role in Health and Disease; Kovalyov, O., Ed.; Nova Science Publishers: Hauppauge, NY, USA, 2020; Chapter 3, pp. 159-181.

25. Gomes, J.; Teixeira, P.; Barbosa, J. Preservation of meat products: Natural antimicrobial agents as an alternative to chemical antimicrobials. In Meat Products: Chemistry, Consumption and Health Aspects; Castro, M.P., Cayré, M.E., Eds.; Nova Science Publishers: Hauppauge, NY, USA, 2021; Chapter 3, pp. 49-87.

26. Woraprayote, W.; Malila, Y.; Sorapukdee, S.; Swetwiwathana, A.; Benjakul, S.; Visessanguan, W. Bacteriocins from lactic acid bacteria and their applications in meat and meat products. Meat Sci. 2016, 120, 118-132. [CrossRef]

27. Nurk, S.; Bankevich, A.; Antipov, D.; Gurevich, A.; Korobeynikov, A.; Lapidus, A.; Prjibelsky, A.; Pyshkin, A.; Sirotkin, A.; Sirotkin, Y.; et al. Assembling Genomes and Mini-metagenomes from Highly Chimeric Reads. In Research in Computational Molecular Biology, Proceedings of the 17th Annual International Conference, RECOMB 2013, Beijing, China, 7-10 April 2013; Lecture Notes in Computer Science; Deng, M., Jiang, R., Sun, F., Zhang, X., Eds.; Springer: Berlin/Heidelberg, Germany, 2013; Volume 7821, pp. 158-170.

28. Bortolaia, V.; Kaas, R.S.; Ruppe, E.; Roberts, M.C.; Schwarz, S.; Cattoir, V.; Philippon, A.; Allesoe, R.L.; Rebelo, A.R.; Florensa, A.F.; et al. ResFinder 4.0 for predictions of phenotypes from genotypes. J. Antimicrob. Chemother. 2020, 75, 3491-3500. [CrossRef]

29. Liu, B.; Zheng, D.; Jin, Q.; Chen, L.; Yang, J. VFDB 2019: A comparative pathogenomic platform with an interactive web interface. Nucleic Acids Res. 2019, 47, D687-D692. [CrossRef]

30. Van Heel, A.J.; de Jong, A.; Song, C.; Viel, J.H.; Kok, J.; Kuipers, O.P. BAGEL4: A user-friendly web server to thoroughly mine RiPPs and bacteriocins. Nucleic Acids Res. 2018, 46, W278-W281. [CrossRef] 
31. Hammami, R.; Zouhir, A.; Le Lay, C.; Ben Hamida, J.; Fliss, I. BACTIBASE second release: A database and tool platform for bacteriocin characterization. BMC Microbiol. 2010, 10, 22. [CrossRef]

32. Altschul, S.F.; Madden, T.L.; Schaffer, A.A.; Zhang, J.; Zhang, Z.; Miller, W.; Lipman, D.J. Gapped BLAST and PSI-BLAST: A new generation of protein database search programs. Nucleic Acids Res. 1997, 25, 3389-3402. [CrossRef]

33. Van Reenen, C.A.; Dicks, L.M.T.; Chikindas, M.L. Isolation, purification and partial characterization of plantaricin 423, a bacteriocin produced by Lactobacillus plantarum. J. Appl. Microbiol. 1998, 84, 1131-1137. [CrossRef]

34. McLauchlin, J.; Hampton, M.D.; Shah, S.; Threlfall, E.J.; Wieneke, A.A.; Curtis, G.D.W. Subtyping of Listeria monocytogenes on the basis of plasmid profiles and arsenic and cadmium susceptibility. J. Appl. Microbiol. 1997, 83, 381-388. [CrossRef]

35. Yang, R.; Monty, J.; Ray, B. Novel method to extract large amounts of bacteriocins from lactic acid bacteria. Appl. Environ. Microbiol. 1992, 58, 3355-3359. [CrossRef]

36. Sambrook, J.; Fritsch, E.F.; Maniatis, T. Molecular Cloning: A Laboratory Manual, 2nd ed.; Malke, H., Ed.; Cold Spring Harbor Laboratory Press: New York, NY, USA, 1989; pp. 1538-1546.

37. Schägger, H.; Von Jagow, G. Tricine-sodium dodecyl sulphate polyacrylamide gel electrophoresis for the separation of protein in the range from 1 to $100 \mathrm{kDa}$. Anal. Biochem. 1987, 166, 368-379. [CrossRef]

38. European Food Safety Authority. Guidance on the assessment of bacterial susceptibility to antimicrobials of human and veterinary importance by EFSA Panel on Additives and Products or Substances used in Animal Feed (FEEDAP). EFSA J. 2012, 10, 2740-2749. [CrossRef]

39. Saelim, K.; Jampaphaeng, K.; Maneerat, S. Functional properties of Lactobacillus plantarum S0/7 isolated fermented stinky bean (Sa Taw Dong) and its use as a starter culture. J. Funct. Foods 2017, 38, 370-377. [CrossRef]

40. Gao, Y.; Liu, Y.; Sun, M.; Zhang, H.; Mu, G.; Tuo, Y. Physiological function analysis of Lactobacillus plantarum Y44 based on genotypic and phenotypic characteristics. J. Dairy Sci. 2020, 103, 5916-5930. [CrossRef]

41. Feriala, A.A.; Saif, A.; Sakr, E.A.E. Characterization and bioactivities of exopolysaccharide produced from probiotic Lactobacillus plantarum 47FE and Lactobacillus pentosus 68FE. Bioact. Carbohydr. Diet. Fibre 2020, 24, 100231. [CrossRef]

42. European Food Safety Authority. EFSA statement on the requirements for whole genome sequence analysis of microorganisms intentionally used in the food chain. EFSA J. 2021, 1-15. Available online: https:/ /www.efsa.europa.eu/sites/default/files/2021 -03/ outcome-public-consultation-for-EFSA-statement-EFSA-Q-2019-00434.pdf (accessed on 17 May 2021).

43. Kleerebezem, M.; Boekhorst, J.; van Kranenburg, R.; Molenaar, D.; Kuipers, O.P.; Leer, R.; Tarchini, R.; Peters, S.A.; Sandbrink, H.M.; Fiers, M.W.E.J.; et al. Complete genome sequence of Lactobacillus plantarum WCFS1. Proc. Natl. Acad. Sci. USA 2003, 100, 1990-1995. [CrossRef]

44. Diep, D.B.; Myhre, R.; Johnsborg, O.; Aakra, Å.; Nes, I.F. Inducible bacteriocin production in Lactobacillus is regulated by differential expression of the $p l n$ operons and by two antagonizing response regulators, the activity of which is enhanced upon phosphorylation. Mol. Microbiol. 2003, 47, 483-494. [CrossRef]

45. Le Marrec, C.; Hyronimus, B.; Bressollier, P.; Verneuil, B.; Urdaci, M.C. Biochemical and genetic characterization of coagulin, a new antilisterial bacteriocin in the Pediocin family of bacteriocins, produced by Bacillus coagulans I4. Appl. Environ. Microbiol. 2000, 66, 5213-5220. [CrossRef]

46. Kumariya, R.; Garsa, A.K.; Rajput, Y.S.; Sood, S.K.; Akhtar, N.; Patel, S. Bacteriocins: Classification, synthesis, mechanism of action and resistance development in food spoilage causing bacteria. Microb. Pathog. 2019, 128, 171-177. [CrossRef] [PubMed]

47. Ennahar, S.; Aoude-Werner, D.; Sorokine, O.; van Dorsselaer, A.; Bringel, F.; Hubert, J.-C.; Hasselmann, C. Production of pediocin AcH by Lactobacillus plantarum WHE 92 isolated from cheese. Appl. Environ. Microbiol. 1996, 62, 4381-4387. [CrossRef]

48. Loessner, M.; Guenther, S.; Steffan, S.; Scherer, S. A Pediocin-producing Lactobacillus plantarum strain inhibits Listeria monocytogenes in a multispecies cheese surface microbial ripening consortium. Appl. Environ. Microbiol. 2003, 69, 1854-1857. [CrossRef]

49. West, C.A.; Warner, P.J. Plantacin B, a bacteriocin produced by Lactobacillus plantarum NCDO 1193. FEMS Microbiol. Lett. 1988, 49, 163-165. [CrossRef]

50. Remiger, A.; Eijsink, V.G.; Ehrmann, M.A.; Sletten, K.; Nes, I.F.; Vogel, R.F. Purification and partial amino acid sequence of plantaricin 1.25 alpha and 1.25 beta, two bacteriocins produced by Lactobacillus plantarum TMW1.25. J. Appl. Microbiol. 1999, 86, 1053-1058. [CrossRef]

51. Holo, H.; Jeknic, Z.; Daeschel, M.; Stevanovic, S.; Nes, I.F. Plantaricin W from Lactobacillus plantarum belongs to a new family of two-peptide lantibiotics. Microbiology 2001, 147, 643-651. [CrossRef]

52. Wang, Y.; Qin, Y.; Xie, Q.; Zhang, Y.; Hu, J.; Li, P. Purification and characterization of plantaricin LPL-1, a novel class IIa bacteriocin produced by Lactobacillus plantarum LPL-1 isolated from fermented fish. Front. Microbiol. 2018, 9, 2276. [CrossRef]

53. Martinez, R.C.R.; Wachsman, M.; Torres, N.I.; LeBlanc, J.G.; Todorov, S.D.; Franco, B.D.G.M. Biochemical, antimicrobial and molecular characterization of a noncytotoxic bacteriocin produced by Lactobacillus plantarum ST71KS. Food Microbiol. 2013, 34, 376-381. [CrossRef]

54. Peng, S.; Song, J.; Zeng, W.; Wang, H.; Zhang, Y.; Xin, J.; Suo, H. A broad-spectrum novel bacteriocin produced by Lactobacillus plantarum SHY 21-2 from yak yogurt: Purification, antimicrobial characteristics and antibacterial mechanism. LWT 2021, 142, 110955. [CrossRef]

55. Wang, Y.; Shang, N.; Qin, Y.; Zhang, Y.; Zhang, J.; Li, P. The complete genome sequence of Lactobacillus plantarum LPL-1, a novel antibacterial probiotic producing class IIa bacteriocin. J. Biotechnol. 2018, 266, 84-88. [CrossRef] 
56. Pei, J.; Jin, W.; Abd El-Aty, A.M.; Baranenko, D.A.; Gou, X.; Zhang, H.; Geng, J.; Jiang, L.; Chen, D.; Yue, T. Isolation, purification, and structural identification of a new bacteriocin made by Lactobacillus plantarum found in conventional kombucha. Food Control 2020, 110, 106923. [CrossRef]

57. Manzoor, A.; Tayyeb, A. Functional probiotic attributes and gene encoding plantaracin among variant Lactobacillus plantarum strains. Microb. Pathog. 2019, 131, 22-32. [CrossRef] [PubMed]

58. Handa, S.; Sharma, N. In vitro study of probiotic properties of Lactobacillus plantarum F22 isolated from chhang-A traditional fermented beverage of Himachal Pradesh, India. J. Genet. Eng. Biotechnol. 2016, 14, 91-97. [CrossRef]

59. Todorov, S.D.; Prévost, H.; Lebois, M.; Dousset, X.; LeBlanc, J.G.; Franco, B.D.G.M. Bacteriocinogenic Lactobacillus plantarum ST16Pa isolated from papaya (Carica papaya) —From isolation to application: Characterization of a bacteriocin. Food Res. Int. 2011, 44, 1351-1363. [CrossRef]

60. Wen, L.S.; Philip, K.; Ajam, N. Purification, characterization and mode of action of plantaricin K25 produced by Lactobacillus plantarum. Food Control 2016, 60, 430-439. [CrossRef]

61. Todorov, S.D.; Dicks, L.M.T. Lactobacillus plantarum isolated from molasses produces bacteriocins active against Gram-negative bacteria. Enzyme Microb. Technol. 2005, 36, 318-326. [CrossRef]

62. Powell, J.E.; Witthuhn, R.C.; Todorov, S.D.; Dicks, L.M.T. Characterization of bacteriocin ST8KF produced by a kefir isolate Lactobacillus plantarum ST8KF. Int. Dairy J. 2007, 17, 190-198. [CrossRef]

63. Wang, L.; Zhang, H.; Rehman, M.U.; Mehmood, K.; Jiang, X.; Iqbal, M.; Tong, X.; Gao, X.; Li, J. Antibacterial activity of Lactobacillus plantarum isolated from Tibetan yaks. Microbial Pathogenesis. Microb. Pathog. 2018, 115, 293-298. [CrossRef]

64. Todorov, S.; Onno, B.; Sorokine, O.; Chobert, J.M.; Ivanova, I.; Dousset, X. Detection and characterization of a novel antibacterial substance produced by Lactobacillus plantarum ST31 isolated from sourdough. Int. J. Food Microbiol. 1999, 48, 167-177. [CrossRef]

65. Todorov, S.D.; Dicks, L.M.T. Effect of growth medium on bacteriocin production by Lactobacillus plantarum ST194BZ, a strain isolated from boza. Food Technol. Biotechnol. 2005, 43, 165-173.

66. Hu, M.; Zhao, H.; Zhang, C.; Yu, J.; Lu, Z. Purification and characterization of plantaricin 163, a novel bacteriocin produced by Lactobacillus plantarum 163 isolated from traditional Chinese fermented vegetables. J. Agric. Food Chem. 2013, 61, 11676-11682. [CrossRef] [PubMed]

67. Sidhu, P.K.; Nehra, K. Purification and characterization of bacteriocin Bac23 extracted from Lactobacillus plantarum PKLP5 and its interaction with silver nanoparticles for enhanced antimicrobial spectrum against food-borne pathogens. LWT 2021, 139, 110546. [CrossRef] 